\title{
RESEARCH SECTION
}

The Committee on Organization of Investigations in Secondary Education met in the Blue Room of Hotel Tuller on Wednesday, February 25. Professor W. C. Reavis of the University of Chicago called the meeting to order at 9:40 A. M.

Professor George E. Carrothers of the School of Education of the University of Michigan led the discussion of The Teaching Load. The outline of his talk follows:

\section{QUESTIONS CONCERNING THE TEACHING LOAD}

J. B. Edmonson and Grorge E. Carrothers,

\section{UNIVERSity OF Michigan}

I. How does the load of the teacher compare with:

(1) The load of other government employees?

(2) That of heads of departments in stores and workers in business and industry holding corresponding positions?

(3) The work accomplished by lawyers, doctors, and other professional men and women?

(4) The load carried by women in the home?

(5) The load which the public of ten thinks is carried?

II. Does the work of the teacher seem heavier and more exacting since:

(1) The teacher deals with human beings almost all the time and under restricted conditions?

(2) The teacher deals with immature rather than with mature human beings?

(3) The teacher deals with boys and girls who do not choose their schools and teachers, or even choose to go to school?

(4) There is to-day a better understanding of child nature, or is the work thus made lighter?

(5) The curriculum is greatly enriched and broadened?

(6) The youth of this day appear to be quite sophisticated? 
(7) Better measuring rods are now available for use by school administrators?

(8) The compensation is a stated, previously known amount which is not always related to the amount or quality of service rendered?

(9) The results of efficient teaching are extremely difficult to show to the public?

(10) The work of the school is considered everybody's business?

III. To what extent can administrators help to lighten the teaching load by :

(1) Selecting teachers who have developed efficient work habits?

(2) Properly inducting teachers into their new positions?

(3) A careful distribution of the teaching load?

(4) Helping in the development and maintenance of a wholesome staff morale?

(5) Encouraging staff teamwork and coöperation?

(6) Assisting in the grouping of pupils according to their ability?

(7) Providing good teaching materials and equipment, mimeographing service, and needed clerical assistance?

(8) Working with entire staff in the discovery and use of more efficient methods of teaching?

(9) Selecting helpful, coöperative supervisors?

(10) Developing an efficient administrative policy?

(11) Disregarding and working to eliminate petty regulations which tend to repress and restrict teachers?

(12) Encouraging initiative and sense of responsibility through the giving of due credit and recognition for work well done?

V. To what extent can teachers help in lightening their own loads by :

(1) A more careful planning and preparation of daily work?

(2) Making assignments clear and definite, and setting teaching goals in the form of problems?

(3) Teaching pupils useful study habits? 
(4) Having pupil monitors take the roll and assist in collecting and distributing materials?

(5) Opening the class on time with some definite work that will involve all the class?

(6) Giving five-minute written quizzes in order to test daily preparation?

(7) Giving true-false, completion or association tests rather than the long essay type of examination?

(8) Developing a spirit and plan of coöperation which will tend toward the holding of pupils responsible for good penmanship, good English, correct mathematics, etc. in every school activity?

(9) Avoiding the common practice of saving examination papers or other large tasks for Saturday or Sunday?

(10) Using standardized tests so that pupils may know definitely their standing as compared with that of other pupils?

(11) Developing a work-play-recreation-professional-development program suited to oneself?

Mr. Richard E. Rutledge, Director of Research of the Oakland Public Schools, Oakland, California presented the following report:

A STUDY OF THE STATUS OF THE SUBJECT SUPERVISOR IN THE JUNIOR AND SENIOR HIGH SCHOOLS OF THE LARGEST 100 CITIES OF THE UNITED STATES

\section{The Problem}

At the suggestion of members of the San Francisco Bay Section of the National Education Association Committee on the Organization of Investigations in Secondary Education this study was undertaken by three of its number. The objective of the study was to determine the administrative relationship existing between the subject supervisor, principal and superintendent as shown by certain practices in city school systems.

\section{Delimitations of the Problem}

Realizing that only the largest cities would be likely to employ subject supervisors it was decided to confine the study to the largest 